\title{
AIRFLOW MEASUREMENT TEST DEVICE FOR AIRFLOW SENSORS
}

\author{
Tatiana Kelemenová \\ Technical University of Kosice, Faculty of Mechanical Engineering, Letna 9, Kosice, Slovak Republic, EU, \\ tatiana.kelemenova@tuke.sk
}

Keywords: measurement, education, airflow, anemometer

Abstract: The paper deals with didactic model of test device for testing of airflow sensors and measurement equipment's. The test device contains from source of wind flow with regulator, flow channel with place for the testing of airflow sensors or anemometers. Students can have training with working with sensors and measurements equipment's and also experience with calibration and verification of sensors.

\section{Introduction}

Nowadays, there are many applications where it is necessary to measure airflow velocity. This measurement is possible to divide into two main groups as:

- Airflow measurements in opened channels.

- Airflow measurements in closed channels.

Area of meteorology uses airflow measurements for weather-forecast. The anemometers are used for the measurement of flow of wind.

Closed channel is represented with tube or pipe and for measurement of airflow is used pitot and Prandtl pipe.

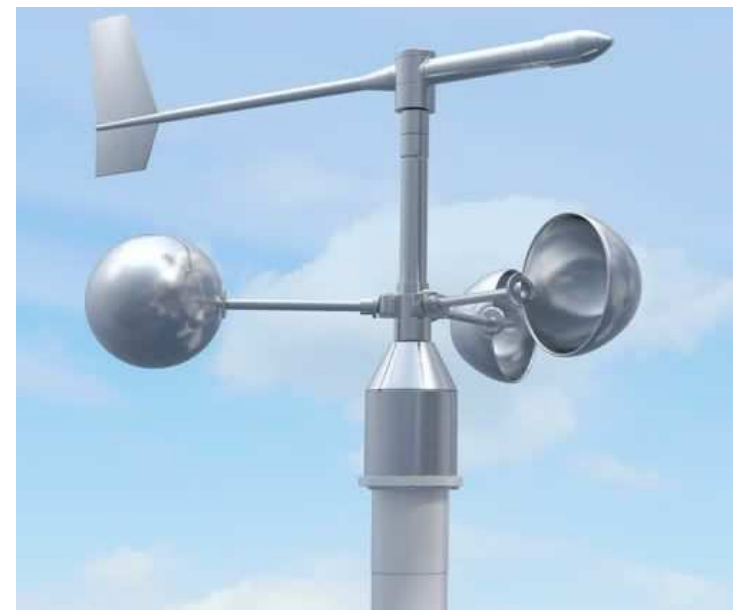

Figure 1 Cup wind anemometer

There are several principles of measurement of airflow. Venturi device is based on principle of reduction of crosssection of flow which causes a pressure differential before and after the cross-section reduction. Airflow measurements is derived from pressure measurement.

Similar principle based on pressure difference uses orifice plate with exactly defined hole diameter and thickness.

Rotameters (Fig. 2) are also famous principle of measurement of airflow. Principle is based on flow of air through the tube with continually increased cross-section where float is lifted with airflow. Float is stabilized in position where gravity force and force from flow are in equilibrium. This position gives information about the airflow velocity.

Ultrasonic principle is principle, where we cannot change anything inside tube. Ultrasonic transducer is attached to outer side of pipe wall and uses two type of principle as Doppler principle and time to flight principle.

Cup wind anemometer is used for airflow measurement on opened space also frequently called as wind speed anemometer. Change of wind speed causes the change of velocity rotation of vertical shaft with horizontal arms with spherical cups (Fig. 1).
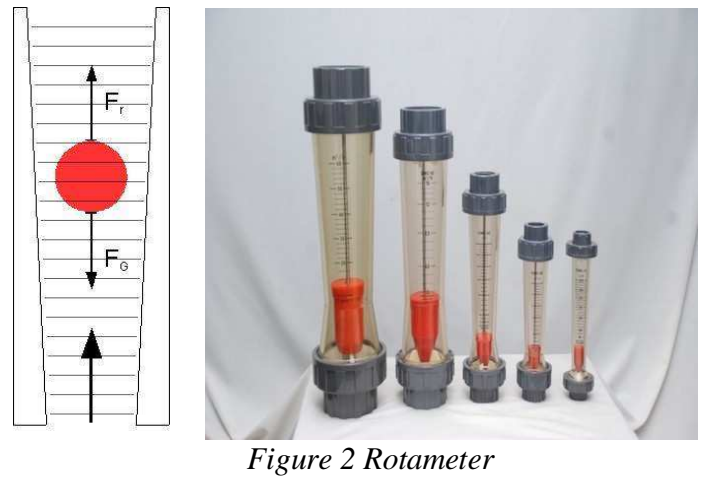

Vane anemometer (Fig. 3) is also suitable for wind speed measurement. It uses the propeller on horizontal axis in wind direction.

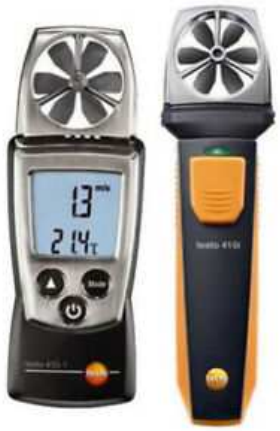

Figure 3 Vane anemometer 


\section{AIRFLOW MEASUREMENT TEST DEVICE FOR AIRFLOW SENSORS}

Tatiana Kelemenová

Hot-wire (Fig. 4) anemometer uses the thin wire, which is electrically heated. Airflow causes the decreasing of wire temperature.

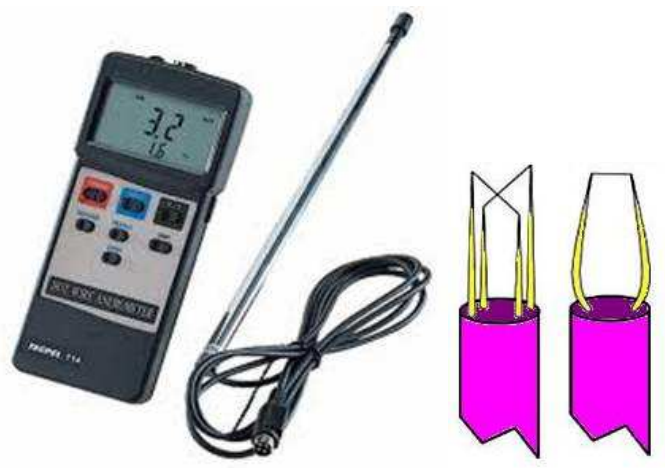

Figure 4 Hot wire anemometer

Controller has to compensate it with higher electric current which gives information about airflow velocity measurement. Advantage is that, there is no moving parts $[1-5]$.

\section{Testing device for airflow measurement}

Model of system consists of big fan BL6800 as source of airflow with tube for stabilization of airflow and Prandtl tube also called as pitot static tube (Fig. 5) used as reference measurement of airflow.

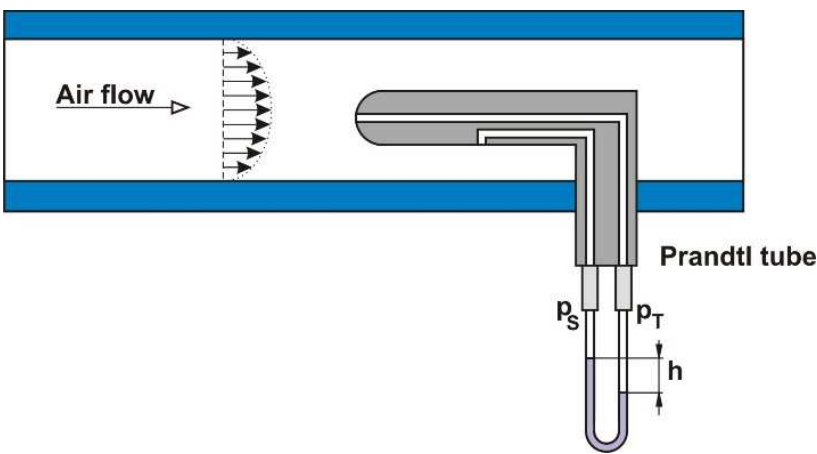

Figure 5 Concept of Prandtl tube measurement

Prandtl tube has one tube hole in flow direction which measures the total pressure composed from static pressure and dynamic pressure. Second input hole - static port is placed on side of Prandtl probe. Both input ports are connected with output terminal on Prandtl tube (Fig. 5). Both terminals are connected to U-tube manometer for measurement of pressure difference. Also, different type of manometer can be used. U-type manometer can be used only in vertical position, because it includes liquid filling.

The velocity of airflow along the cross-section is not constant. The configuration with static pitot tube also allows the measurement of velocity profile of airflow along the cross-section of tube, where we measure airflow velocity. Pitot tube is also used for velocity measurement of aeroplane. In this case pitot tube also includes heater as prevention of frost cover, which can disable the functionality of pitot tube.
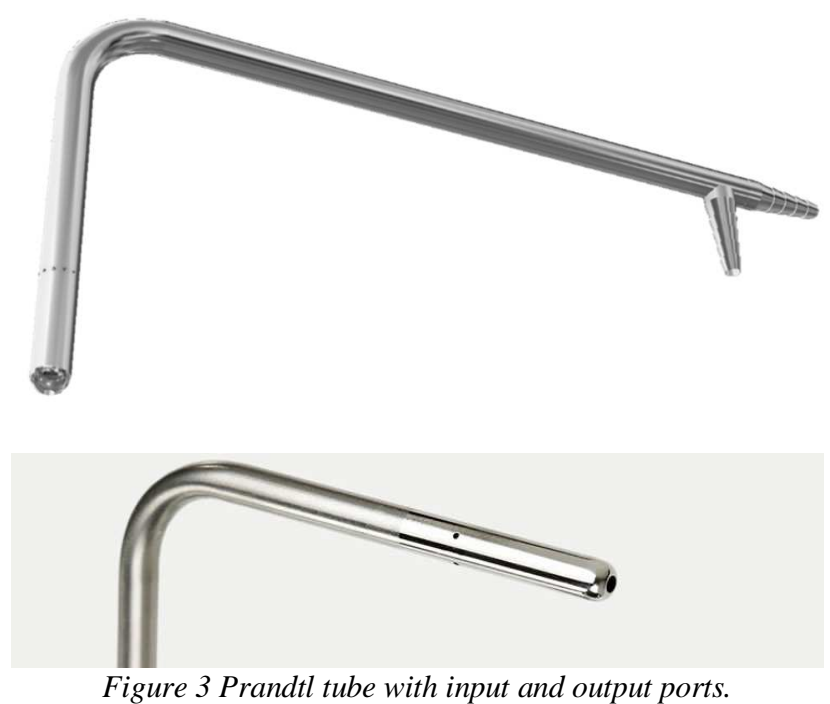

Blower MASTER BL 6800 (Fig. 4) has been used as source of airflow. This is an excellent source because it provides air pressure $388 \mathrm{~Pa}$ and air displacement $3900 \mathrm{~m}^{3} / \mathrm{h}$. It has robust and stabile design.

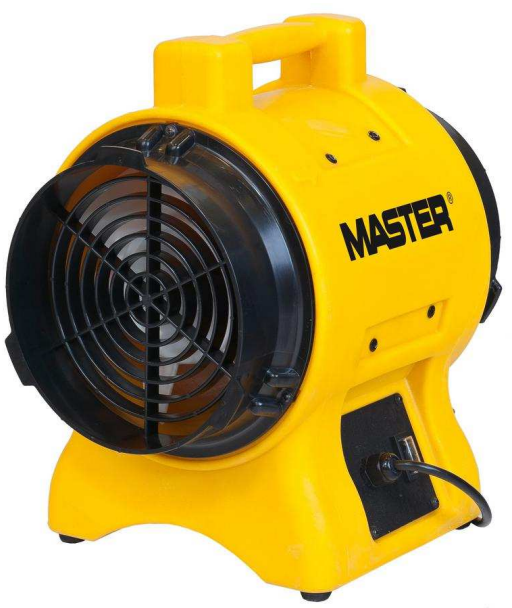

Figure 4 Blower MASTER BL 6800

It has terminal with bayonet lock for connecting of tube. Blower has one constant speed and for our purpose it is connected with speed controller RS 10,0 T (Fig. 5). It is normally used in ventilation and air conditioning systems to control the output of single-phase fans by means of smooth variation of the voltage supplied to the motor. The controller operation is based on changing the output voltage. The controller body is made of non-combustible thermoplastic. The controller is equipped with an ON/OFF button. The power output is modulated from 25 to $100 \%$. 


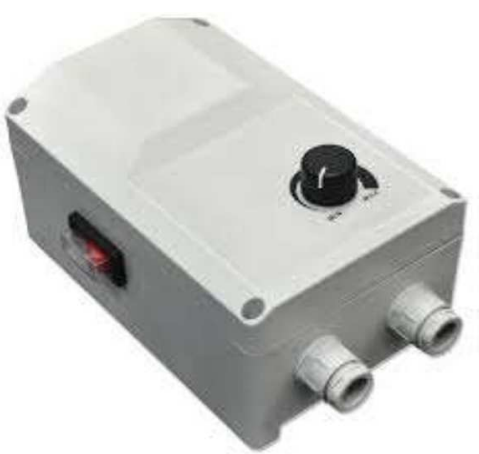

Figure 5 Speed controller RS 10,0 T

Overall setting up is shown on figure 6. Blower (1) is connected to the conical reduction (2) and stabilization tube (3). Speed controller (4) is connected to the blower (1). Hot wire anemometers (5) and (6) are tested and installed in hole. Also, vane anemometer (7) is installed for testing.

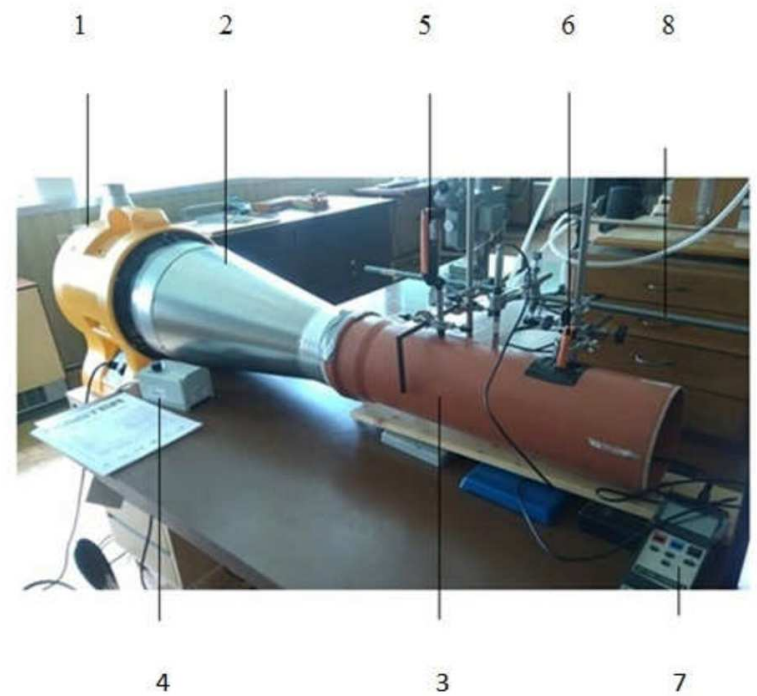

Figure 6 Change of the position of robot chassis

All tested anemometers (Fig. 7) are compared with static pitot tube. Data from all tested anemometers will be compared.

Velocity of airflow measured on pitot tube is defined with equation:

$$
w=\sqrt{2 \cdot \frac{p_{d}}{\rho}}=\sqrt{2 \cdot \frac{q \cdot s}{\rho}}
$$

\section{Where}

$w$ - airflow velocity; $q$ - kinetic pressure; $\rho$ - air density; $p_{d}-$ dynamic pressure $p_{T}-$ total pressure; $s-$ compress ability (liquids $s=1$; gasses $s \neq 1$ ).

For kinetic pressure it is possible to derive equation:

$$
q=\frac{\rho}{2} \cdot w^{2}
$$

Pressure difference can be measured via using the Utube and for this case it can be derived as:

$$
\Delta p=p_{T}-p_{S}=h \cdot \rho \cdot g
$$

Where $h$ is height of liquid bar in U-tube and $g$ is gravitational constant.
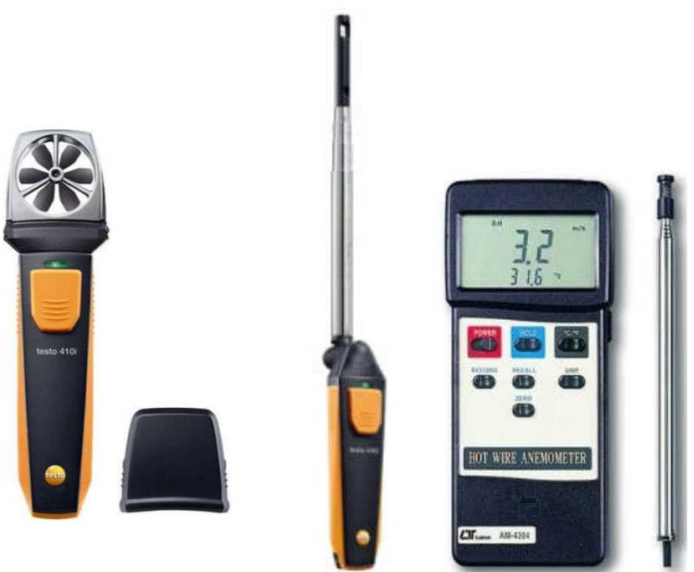

Figure 6 Vane anemometer and two hot wire anemometers

\section{Experimental results}

All mentioned anemometers are tested on designed testing device. Ten measurements measured during the constant velocity is shown on figure 7 .

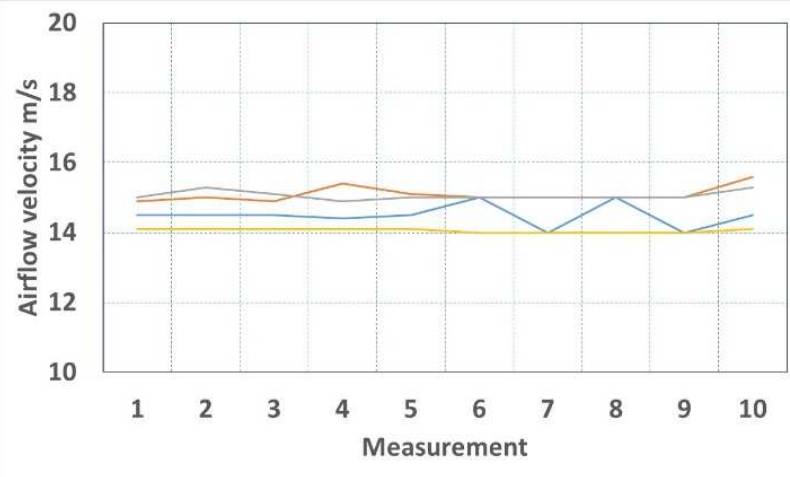

- Hot wire 1 -Vane anemometer - Hot wire 2 - U tube

Figure 7 Simulation of locomotion for selection of drive servomechanism for wheels

Measured data are relatively stable and it is close to the reference value. Blower has been adjusted to ten different values and it brought the ten various values of airflow velocity. From this data the averages have been done for comparing the results with reference value. It is shown on figure 8 . 


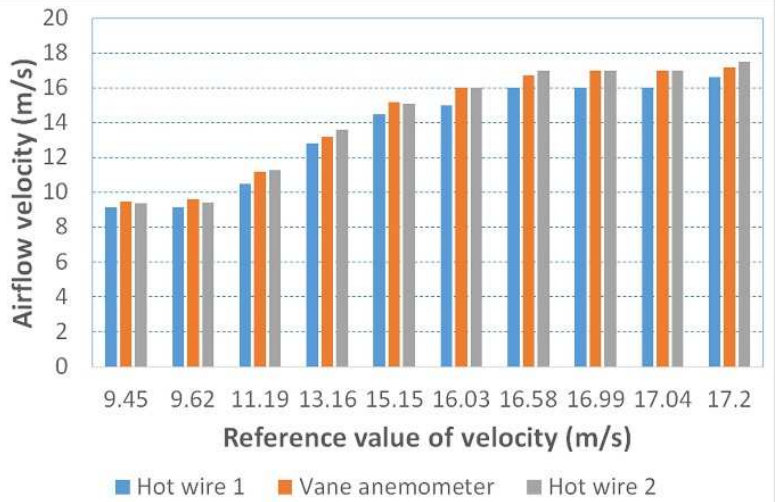

Figure 8 Verification of anemometers value with reference value

After comparing with reference value, measurement error is shown on figure 9. Vane anemometer has the best results from the viewpoint of measurement error.

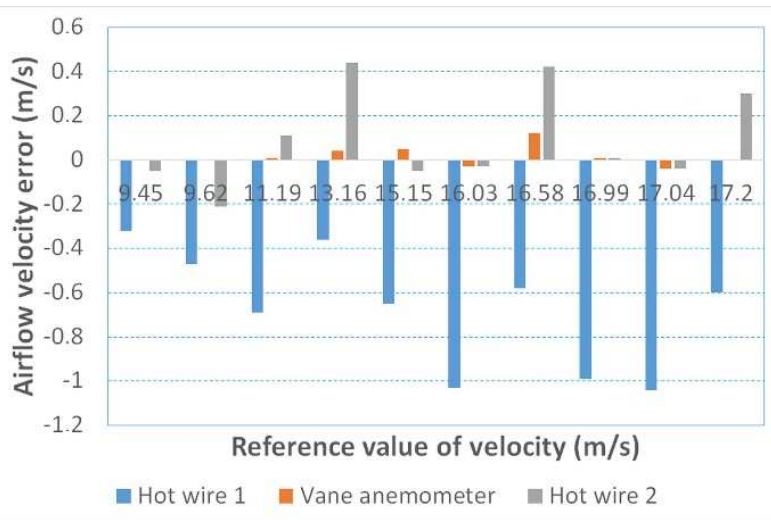

Figure 9 Airflow measurement error

On the base of valid standards [6-9], it is possible to make computation of uncertainty of measurements for comparison of measuring devices (fig. 10).

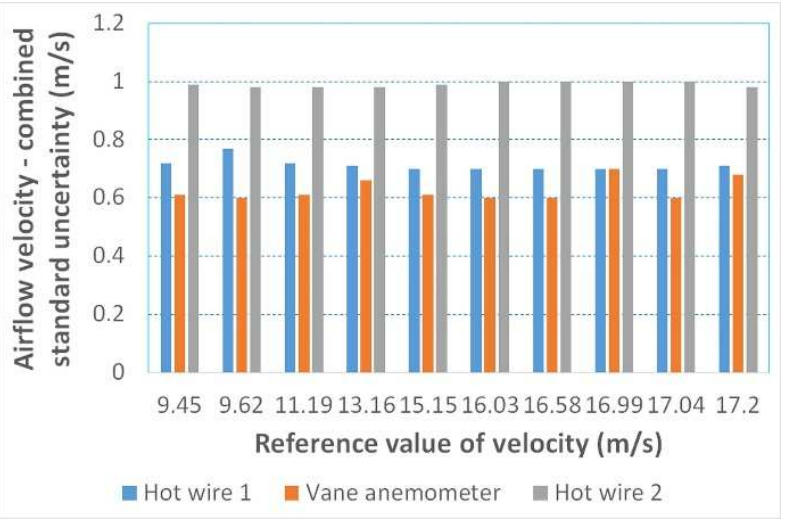

Figure 10 Combined uncertainty of airflow measurements

Vane anemometer also has the best values of combined uncertainty of measurements (fig. 10).

\section{Conclusion}

The aim of this work was to build the test device and to make a test the available anemometers. The best results have a vane anemometer. On the base of these results, it is possible to declare the uncertainty of measurements and systematic error of measurements.

All measure device should be periodically verified for accessible measurement error and uncertainty fir receive the valid results of measurements [10-26].

\section{Acknowledgement}

The work has been accomplished under the research project APVV-15-0149, VEGA 1/0224/18, KEGA 006STU-4/2018 financed by the Slovak Ministry of Education.

\section{References}

[1] KLOPFENSTEIN Jr., R.: Air velocity and flow measurement using a Pitot tube, ISA Transactions, Vol. 37, No. 4, pp. 257-263, 1998. doi:10.1016/S00190578(98)00036-6

[2] YANOVYCH, V., DUDA, D., HORÁČEK, V., URUBA, V.: Research of a wind tunnel parameters by means of cross-section analysis of air flow profiles. AIP Conference Proceedings 2189, 020024, 2019. doi:10.1063/1.5138636

[3] TODA, Y., MORIMATSU, M., NISHIO, Y., OGAWA, T.: Theoretical Model of a Flow in a Tube With a Slit, ASME-JSME-KSME $20198^{\text {th }}$ Joint Fluids Engineering Conference, July 28-August 1, 2019, San Francisco, California, USA. Volume 3A: Fluid Applications and Systems, Paper No: AJKFluids20195257, V03AT03A041, pp. 5, 2019. doi:10.1115/ AJKFluids2019-5257.

[4] FRANCO, L. G., RAMOS, R., MATTOS, M. C., ANDRADE, L. A.: Uncertainty evaluation and experimental analysis fora wind tunnel as reference to gas flare flow measurement, ENCIT 2018-0041 17 th Brazilian Congress of Thermal Sciences and Engineering, November 25th-28th, 2018, Águas de Lindóia, SP, Brazil, 2018.

[5] EA-4/02 M:2013 Evaluation of the Uncertainty of Measurement In Calibration, Publication Reference, European Accreditation Laboratory Committee, September 2013 rev 01. cited August $8^{\text {th }}, 2019$, Online, Available: https://european-accreditation.org/wpcontent/uploads/2018/10/ea-4-02-m-rev01-september2013.pdf

[6] JCGM 200:2012, International vocabulary of metrology - Basic and general concepts and associated terms (VIM), $3^{\text {rd }}$ edition, BIPM, 2012.

[7] JCGM 100 - Evaluation of measurement data - Guide to the expression of uncertainty in measurement (ISO/IEC Guide 98-3), $1^{\text {st }}$ edition, September 2008, Online, Available: http://www.iso.org/sites/JCGM/GU 
M-JCGM100.htm, http://www.bipm.org/en/ publications/guides/gum_print.html

[8] MSA-L/11 Guidelines on the expressions of uncertainty in quantitative testing (EA - 4/16: 2003), Guidelines on the expression of uncertainty in quantitative testing, Slovak national accreditation service, SNAS BRATISLAVA, August 2009. (Original in Slovak)

[9] MSA-L/12 Expression of the uncertainty of measurement in calibration, (EA-4/02) - Expression of the uncertainty of measurement in calibration, Slovak National Accreditation Service, SNAS BRATISLAVA, November 2010. (Original in Slovak)

[10] PALENCAR, R., SOPKULIAK, P., PALENCAR, J., ĎURIŠ, S., SUROVIAK, E., HALAJ, M.: Application of Monte Carlo method for evaluation of uncertainties of ITS-90 by standard platinum resistance thermometer, Measurement Science Review, Vol. 17, No. 3, pp. 108-116, 2017.

[11] WIMMER, G., PALENĆÁR, R., WITKOVSKÝ, V.: Stochastic models of measurement, Graphic studio Ing. Peter Juriga, L. Fullu 13, 84105 Bratislava, $1^{\text {st }}$ ed., 2001. (Original in Slovak)

[12] BOŽEK, P., CHMELÍKOVÁ, G.: Virtual Technology Utilization in Teaching, Conference ICL2011, September 21-23, 2011 Piešt'any, Slovakia, pp. 409413. 2011.

[13] TURYGIN, Y., BOŽEK, P.: Mechatronic systems maintenance and repair management system, Transfer of innovations, Vol. 26, pp. 3-5, 2013.

[14] HARGAŠ , L, HRIANKA, M, KONIAR, D, IZÁK, P.: Quality Assessment SMT Technology by Virtual Instrumentation, Applied Electronics 2007, 2007.

[15] SPANIKOVA, G., SPANIK, P., FRIVALDSKY, M., PAVELEK, M., BASSETTO, F., VINDIGNI, V.: Electric model of liver tissue for investigation of electrosurgical impacts, Electrical Engineering, Vol. 99, pp. 1185-1194, 2017.

[16] KARAVAEV, Y. L., KILIN, A. A.: Nonholonomic dynamics and control of a spherical robot with an internal omniwheel platform: Theory and experiments, Proceedings of the Steklov Institute of Mathematics, Vol. 295, No. 1, pp. 158-167, 2016.

[17] KURIC, I., BULEJ, V., SAGA, M., POKORNÝ, P.: Development of simulation software for mobile robot path planning within multilayer map system based on metric and topological maps, International Journal of
Advanced Robotic Systems, Vol. 14, No. 6, pp. 1-14, 2017.

[18] KIM, Y.-S., JUNG, G.-P., KIM, H., CHO, K.-J. AND CHU, C.-N.: Wheel Transformer: A Miniaturized Terrain Adaptive Robot with Passively Transformed Wheels, Proceedings of the IEEE/RSJ International Conference on Robotics and Automation, Karlsruhe, Germany, pp. 5625-5630, 2013.

[19] LEE, D.-Y., KOH, J.-S., KIM, J.-S., KIM, S.-W., CHO, K.-J.: Deformable-wheel robot based on soft material, International Journal of Precision Engineering and Manufacturing, Vol. 14, No. 8, pp. 1439-1445, 2013.

[20] MATSUNO, F., TADOKORO, S.: Rescue Robots and Systems in Japan, Proceedings of the IEEE International Conference on Robotics and Biomimetics, New Orleans, LA, USA, pp. 12-20, 2004.

[21] BRUZZONE, L., QUAGLIA, G.: Review article: Locomotion systems for ground mobile robots in unstructured environments, Mechanical Sciences, Vol. 3, No. 2, pp. 49-62, 2012.

[22] VIRGALA, I., MIKOVÁ, L., KELEMEN, M., HRONCOVÁ, D.: Snake-like robots, Acta Mechatronica, Vol. 3, No. 4, pp. 7-10, 2018. doi: 10.22306/am.v3i4.43

[23] MIKOVÁ, L., VIRGALA, I., KELEMEN, M.: Embedded systems, Acta Mechatronica, Vol. 3, No. 2, pp. 1-5, 2018. doi:10.22306/am.v3i2.32

[24] KELEMENOVÁ, T., FRANKOVSKÝ, P., VIRGALA, I., MIKOVÁ, L., KELEMEN, M., DOMINIK, L.: Educational models for mechatronic courses, Acta Mechatronica, Vol. 1, No. 4, pp. 1-6, 2016.

[25] LIPTÁK, T., KELEMEN, M., GMITERKO, A., VIRGALA, I., HRONCOVÁ, D.: THE CONTROL OF HOLONOMIC SYSTEM, Acta Mechatronica, Vol. 1, No. 2, pp. 15-20, 2016.

[26] PIRNÍK, R., HRUBOŠ, M., NEMEC, D., BOŽEK, P.: Navigation of the autonomous ground vehicle utilizing low-cost inertial navigation, Acta Mechatronica, Vol. 1, No. 1, pp. 19-23, 2016.

\section{Review process \\ Single-blind peer review process.}

